\title{
PENGARUH KONSENTRASI BENZILADENIN (BA) PADA PERTUMBUHAN SPATIFILUM (Spathiphyllum wallisii)
}

\author{
Effect of Benzyladenine (BA) Concentration on Spatifilum \\ (Spathiphyllum wallisii) Growth
}

Rugayah $^{1 *}$, Nurrahmawati ${ }^{1}$, Kus Hendarto ${ }^{1}$, Ermawati ${ }^{1}$

${ }^{1}$ Jurusan Agroteknologi, Fakultas Pertanian, Universitas Lampung

Jl. Sumantri Brojonegoro No 1 Gedung Meneng, Bandar Lampung 35145

*E-mail Korespondensi: rugayah.1961@fp.unila.ac.id

\begin{abstract}
ABSTRAK
Spatifilum (Spathiphyllum wallisii) merupakan tanaman hias populer yang dapat digunakan sebagai dekorasi dalam ruangan sehingga penampilannya harus menarik. Selain pembungaan, kriteria penampilan spatifilum yang menarik adalah memiliki anakan banyak sehingga nampak rimbun. Salah satu upaya untuk mendapatkan tampilan tersebut adalah pemberian zat pengatur tumbuh yang mampu mempercepat pertumbuhan tunas, yaitu Benziladenin (BA). Tujuan penelitian ini adalah untuk mengetahui konsentrasi BA yang menghasilkan pengaruh terbaik terhadap pertumbuhan spatifilum. Penelitian ini dilaksanakan di rumah kaca Gedung Hortikultura, Fakultas Pertanian, Universitas Lampung dari Juli 2019 sampai Januari 2020. Penelitian ini disusun dalam rancangan perlakuan faktor tunggal terstruktur yang terdiri dari enam perlakuan konsentrasi BA yaitu $0 \mathrm{ppm}$, $10 \mathrm{ppm}, 20 \mathrm{ppm}, 30 \mathrm{ppm}, 40 \mathrm{ppm}$, dan $50 \mathrm{ppm}$ dengan enam kali ulangan. Analisis data menggunakan standar deviasi yang disajikan dalam bentuk histogram dengan mengambil nilai ratarata dari setiap perlakuan. Hasil penelitian menunjukkan bahwa pemberian benziladenin dengan konsentrasi $10-50 \mathrm{ppm}$ cenderung meningkatkan pertumbuhan spatifilum pada luas daun, tingkat kehijauan daun, waktu muncul anakan, jumlah anakan, waktu muncul bunga, dan jumlah bunga, tetapi tidak berpengaruh pada penambahan tinggi tanaman dan jumlah daun. Pemberian benziladenin konsentrasi $20 \mathrm{ppm}$ sudah meningkatkan pertumbuhan spatifilum pada fase vegetatif, yang ditunjukkan oleh meningkatnya luas daun, tingkat kehijuan daun, jumlah anakan, dan mempercepat waktu muncul anakan. Pengaruh pemberian benziladenin pada fase generatif terlihat pada konsentrasi yang lebih tinggi yaitu pada konsentrasi $50 \mathrm{ppm}$ cenderung waktu muncul kuncup bunganya paling cepat dan jumlah bunganya paling banyak.
\end{abstract}

Kata kunci: Benziladenin, konsentrasi, Spatifillum

\begin{abstract}
Spatifilum (Spathiphyllum wallisii) is a popular ornamental plant that can be used as indoor decoration, so its appearance should be attractive. Apart from flowering, an interesting criteria for the appearance of the spatula is to have many tillers so that it looks lush. One of the efforts to obtain this appearance is the provision of a growth regulator capable of accelerating shoot growth, namely Benzyladenine (BA). The purpose of this study was to determine the concentration of BA which produced the best effect on spatifylum growth. This research was conducted in the greenhouse of the Horticulture Building, Faculty of Agriculture, University of Lampung from July 2019 to January 2020. This research was arranged in a structured single factor treatment design consisting of six BA concentration treatments, namely $0 \mathrm{ppm}, 10 \mathrm{ppm}, 20 \mathrm{ppm}, 30 \mathrm{ppm}, 40 \mathrm{ppm}$, and $50 \mathrm{ppm}$ with six repetitions. Data analysis used standard deviation which is presented in the form of a histogram by taking the average value of each treatment. The results showed that the administration of benzyladenine with concentrations 10-50 ppm tended to increase spatifylum growth in the variable leaf area, leaf greenness, tiller emergence, number of tillers, flower emergence time, and number of
\end{abstract}


flowers, but had no effect on the addition of plant height and number of leaves. Giving benzyladenine with a concentration of 20 ppm was quite efficient in optimizing the vegetatif growth of spatilum, which was shown by the increase in plant height, increased number of leaves, time to emergence of tillers, and number of tillers. On the other hand, the effect of benziladenine on the generative phase requires a higher concentration, namely at a concentration of $50 \mathrm{ppm}$, the time for which the flower buds appear is faster and the number of flowers is beter.

Keywords: Benzyladenine, concentration, Spatifillum

\section{PENDAHULUAN}

Indonesia memiliki kekayaan flora yang begitu melimpah dengan berbagai keindahan dan keunikan. Ribuan jenis tanaman hias tersebar di seluruh daerah dan belum dimanfaatkan secara optimal. Salah satunya yaitu spatifilum (Spathiphyllum wallisii). Spatifilum merupakan tanaman hias yang memiliki bunga berwarna putih cerah yang kontras dengan warna hijau daun tua sehingga nampak elegan sebagai tanaman hias ruang. Spatifilum ini dapat tumbuh dan berbunga dengan baik di tempat yang tidak terkena cahaya matahari secara langsung atau tanaman indoor. Tanaman spatifilum selain dapat dinikmati keindahannya, juga memiliki manfaat terhadap lingkungan seperti mengurangi pencemaran udara atau polutan lainnya. Menurut Agromedia (2010), tanaman spatifilum diketahui dapat menyerap racun atau membersihkan udara dalam ruangan dari polutan seperti benzena dan formaldehida. Dengan demikian spatifilum ini sangat berpotensi untuk dikembangkan.

Nilai keindahan spatifilum terdapat pada anakan yang banyak dengan daun yang rimbun dan setiap anakan muncul bunga. Pada tahap awal untuk meningkatkan nilai keindahan adalah upaya meningkatkan jumlah anakan melalui penggunaan zat pengatur tumbuh (ZPT) yang berasal dari golongan sitokinin. Sitokinin berperan dalam penggandaan dan pembentukan tunas (Yusnita, 2003). Menurut Asra et al. (2020), penambahan sitokinin eksogen pada suatu tumbuhan akan mempengaruhi kadar sitokinin endogen sehingga masa dormansi tumbuhan dapat dipatahkan. Pematahan dormansi tersebut akan bersamaan dengan terbentuknya tunas. Terbentuknya tunas merupakan akibat dari adanya peningkatan respirasi dan mobilisasi gula.

Zat pengatur tumbuh memiliki pengaruh yang bervariasi tergantung susunan kimia dan spesies tanaman. Salah satu zat pengatur tumbuh yang bersifat memacu pertumbuhan tunas dan dapat digunakan untuk perbanyakan anakan yaitu Benziladenin. Benziladenin adalah hormon sitokinin sintetik yang salah satu fungsinya untuk mampu memecah masa istirahat biji (dormansi biji), merangsang pertumbuhan embrio, dan pembentukan organ (Harjadi, 2009).

Salah satu faktor yang mempengaruhi keberhasilan penggunaan hormon yaitu konsentrasi sehingga penggunaan konsentrasi yang tepat penting untuk dikaji dalam penelitian ini agar zat pengatur tumbuh yg diberikan pada tanaman spatifilum dapat memberikan efek yang lebih baik. Pemberian BA menghasilkan pengaruh yang berbeda terhadap pertumbuhan beberapa jenis tanaman, tergantung taraf konsentrasinya. Elbohy (2018) melaporkan penyemprotan zat pengatur tumbuh GA3 dan kinetin serta pupuk mikro meningkatkan pertumbuhan dan pembungaan tanaman spatifilum.

Hasil penelitian Rugayah et al. (2012) menunjukkan bahwa aplikasi BA pada tanaman pisang Ambon Kuning dengan konsentrasi $50 \mathrm{ppm}$ mampu menghasilkan persentase tunas paling tinggi $(91,67 \%)$ dibandingkan dengan konsentrasi 100 ppm. Benziladenin juga banyak digunakan untuk memacu pertunasan pada tanaman umbi, yaitu pada tanaman gladiol dan kentang. Hasil penelitian Andalasari (2011) menunjukkan bahwa pemberian BA dengan 
konsentrasi 30 ppm pada gladiol Varietas Kaifa mampu meningkatkan jumlah mata tunas aktif hingga 4,6 dan jumlah tunas hingga 6,4 .

Pemberian benziladenin pada spatifilum diharapkan dapat memperbanyak tunas dalam waktu yang lebih cepat. Setiap anakan yang tumbuh berpotensi menghasilkan bunga. Dengan demikian peningkatan jumlah anakan mampu meningkatkan pertumbuhan spatifilum. Penelitian ini dilakukan untuk mengetahui pengaruh konsentrasi BA terhadap pertumbuhan spatifilum yang terbaik.

\section{METODE PENELITIAN}

Penelitian ini dilakukan di rumah kaca Fakultas Pertanian, Universitas Lampung dari bulan Juli 2019 sampai Januari 2020. Penelitian ini disusun dalam rancangan perlakuan faktor tunggal terstruktur yang terdiri dari enam perlakuan konsentrasi dan enam kali ulangan. Perlakukan tunggal yang digunakan adalah konsentrasi benziladenin (B) dengan enam taraf konsentrasi yaitu: 0 ppm ( $\left.b_{0}\right), 10$ ppm ( $\left.b_{1}\right), 20$ ppm ( $\left.b_{2}\right), 30$ ppm $\left(b_{3}\right), 40$ ppm ( $\left.b_{4}\right)$, dan 50 ppm ( $\left.b_{5}\right)$. Bahan tanam berasal dari hasil pemisahan tanaman induk spatifilum yang telah berumur 1,5 tahun yang telah memiliki anakan rata-rata 3-4 anakan.

Anakan spatifilum didapatkan dengan cara membongkar tanaman induk dan dipindahkan ke dalam pot berdiameter 25 $\mathrm{cm}$. Pembongkaran dilakukan dengan cara memisahkan media tanam dari umbi dan akar lalu dipisahkan perakarannya dengan perlahan-lahan agar umbi dan akarnya tidak rusak. Akar tanaman dipotong dengan menyisakan sepanjang $\pm 10 \mathrm{~cm}$ lalu spatifilum direndam dalam fungisida dengan bahan aktif mankozeb 80\% (2 g/l) selama 15-20 menit lalu ditiriskan bahan tanam tersebut siap ditanam.

Media tanam yang digunakan berupa campuran tanah, sekam mentah, dan pupuk kandang dengan perbandingan volume 2:1:1. Persiapan media tanam tersebut dengan cara mencampur dua ember tanah dengan satu ember sekam dan satu ember pupuk kandang, lalu diaduk hingga homogen. Setelah itu media dimasukkan ke dalam pot hingga batas garis pada pot. Setelah itu media tanam disiram dengan larutan fungisida yang berbahan aktif mankozeb 80\% dengan konsentrasi $2 \mathrm{~g} / \mathrm{l}$.

Bibit ditanam ke dalam lubang yang telah dibuat pada media tanam dalam pot. Bibit dibenamkan sampai pangkal batang, kemudian media tanam di sekitarnya dipadatkan. Setiap pot ditanam satu bibit anakan tanaman spatifilum. Saat tanaman umur delapan minggu setelah pindah tanam, dilakukan pemupukan NPK (16:16:16) dengan dosis $5 \mathrm{~g} /$ tanaman.

Aplikasi benziladenin dilakukan dengan cara disiramkan pada titik tumbuh spatifilum sebanyak dua kali dengan interval 4 minggu setelah aplikasi pertama. Volume siram benziladenin pada titik tumbuh sesuai dengan konsentrasi masing-masing sebanyak $50 \mathrm{ml}$ setiap aplikasi, sehingga total volume siram setiap tanaman sebanyak $100 \mathrm{ml}$. Variabel yang diamati pada penelitian ini meliputi: penambahan tinggi tanaman, penambahan jumlah daun, luas daun, tingkat kehijauan daun, waktu muncul anakan (muncul di permukaan tanah dengan tinggi $>3 \mathrm{~cm}$ ), jumlah anakan, waktu muncul kuncup bunga, dan jumlah bunga.

Analisis data menggunakan standar deviasi yang disajikan dalam bentuk histogram dengan mengambil nilai rata-rata dari setiap perlakuan.

\section{HASIL DAN PEMBAHASAN}

Hasil penelitian menunjukkan bahwa pemberian benziladenin dengan konsentrasi 10-50 ppm cenderung menunjukkan adanya peningkatan luas daun, tingkat kehijauan daun, waktu muncul anakan, dan jumlah anakan dibandingkan dengan tanpa pemberian benziladenin. Sebaliknya, pada variabel penambahan tinggi tanaman dan jumlah daun, pemberian benziladenin tidak 
menunjukkan adanya pengaruh. Pemberian benziladenin konsentrasi 30-50 ppm cenderung mempercepat waktu muncul bunga dan jumlah bunga dibandingkan dengan benziladenin konsentrasi 10-20 ppm.

Pemberian BA pada konsentrasi 20 ppm menghasilkan pertumbuhan yang sudah optimum pada fase vegetatif tanaman spatifilum yang ditunjukkan oleh meningkatnya luas daun, tingkat kehijuan daun, jumlah anakan, dan mempercepat waktu muncul anakan (Gambar 3-6). Sebaliknya pengaruh BA pada fase generatif terlihat pada konsentrasi yang lebih tinggi, pada konsentrasi 50 ppm menghasilkan waktu muncul kuncup bunga tercepat dan jumlah bunganya paling banyak (Gambar 78).

Pemberian BA konsentrasi 0-50 ppm tidak menunjukkan adanya perbedaan dalam peningkatan penambahan tinggi tanaman dan jumlah daun. Rata-rata kisaran penambahan tinggi tanaman 4,23-6,32 cm (Gambar 1). Rata-rata kisaran penambahan jumlah daun 7,00-8,17 helai (Gambar 2).

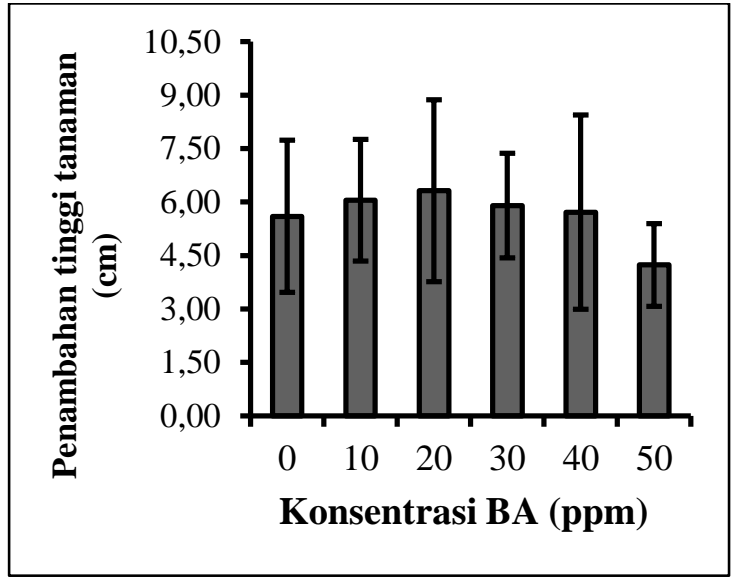

Gambar 1. Pengaruh berbagai konsentrasi benziladenin terhadap penambahan tinggi tanaman spatifilumi.

Salah satu penyebab kurang maksimumnya pengaruh BA pada pertumbuhan spatiphillum diduga karena suhu udara di dalam rumah kaca melebihi batas optimum yang ideal untuk pertumbuhan spatifilum. Suhu dalam rumah kaca berkisar antara $27-38^{\circ} \mathrm{C}$ sedangkan menurut McConnell et al. (2003) tanaman spatifilum dapat tumbuh dengan baik pada suhu yang tidak melebihi $32^{\circ} \mathrm{C}$. Salisbury dan Ross (1995) menyatakan bahwa kenaikan suhu menyebabkan semakin menurunnya kelembaban udara, sehingga proses transpirasi meningkat. Selain itu, suhu yang tinggi dengan berkisar $30-35{ }^{\circ} \mathrm{C}$ dapat menyebabkan stomata menutup yang dapat mencegah masuknya $\mathrm{CO}_{2}$ sebagai salah satu bahan baku untuk fotosintesis. Karbon dioksida yang terhambat untuk masuk ke dalam tanaman dapat menghambat proses fotosintesis sehingga fotosintat yang dihasilkan sedikit dan pertumbuhan tanaman menjadi lambat.

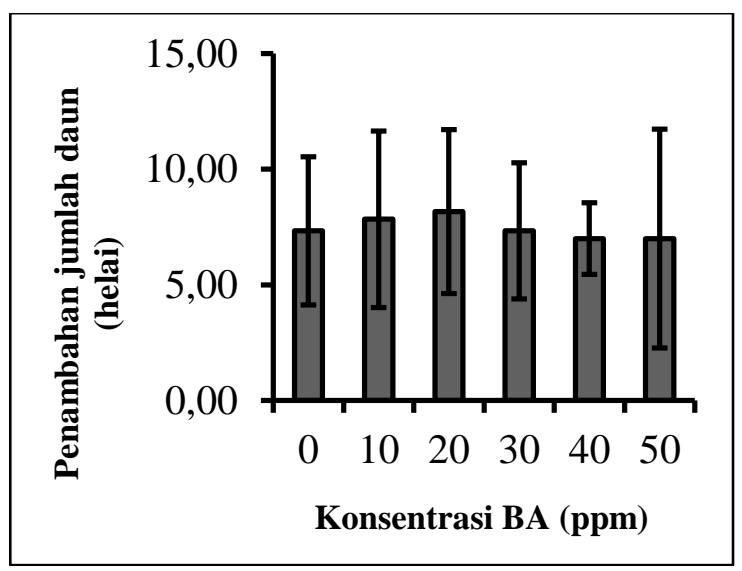

Gambar 2. Pengaruh berbagai konsentrasi benziladenin terhadap penambahan jumlah daun spatifilum.

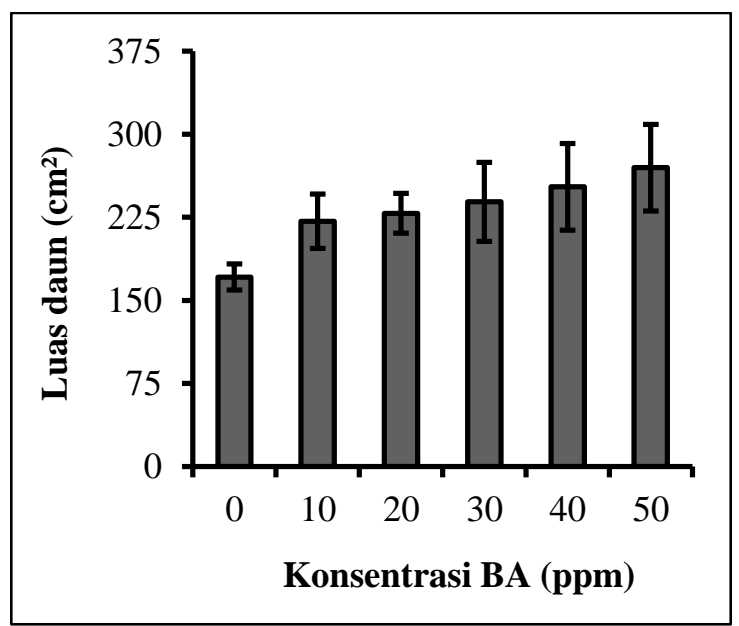

Gambar 3. Pengaruh berbagai konsentrasi benziladenin terhadap luas daun spatifilum. 
Kemungkinan lain penyebab pengaruh pemberian benziladenin yang kurang maksimum diduga kurang terpenuhinya kebutuhan unsur hara untuk spatifilum. Pada penelitian ini, pemupukan yang dilakukan hanya menggunakan pupuk NPK mutiara (16:16:16) dengan dosis 5 g/tanaman. Claudia (2009) melaporkan bahwa pemberian pupuk NPK $(27: 18: 9)$ sebanyak $2 \mathrm{~g} /$ tanaman setiap bulan selama 3 bulan menghasilkan pertumbuhan vegetatif dan generatif yang terbaik pada tanaman spatifilum karena kebutuhan unsur haranya tercukupi. Selain itu juga diberi pupuk daun dengan komposisi 32:10:10 sebanyak 2 g/l disemprotkan pada tanaman tiap 2 minggu mulai umur satu minggu setelah pindah tanam, dan pupuk daun dengan komposisi 10:55:10 (2 g/l) tiap 2 minggu mulai 4 minggu setelah pindah tanam.

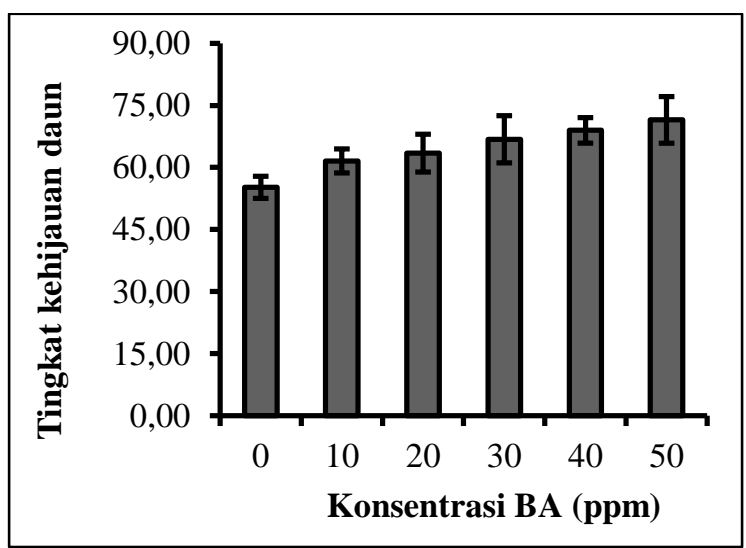

Gambar 4. Pengaruh berbagai konsentrasi benziladenin terhadap tingkat kehijauan daun spatifilum.

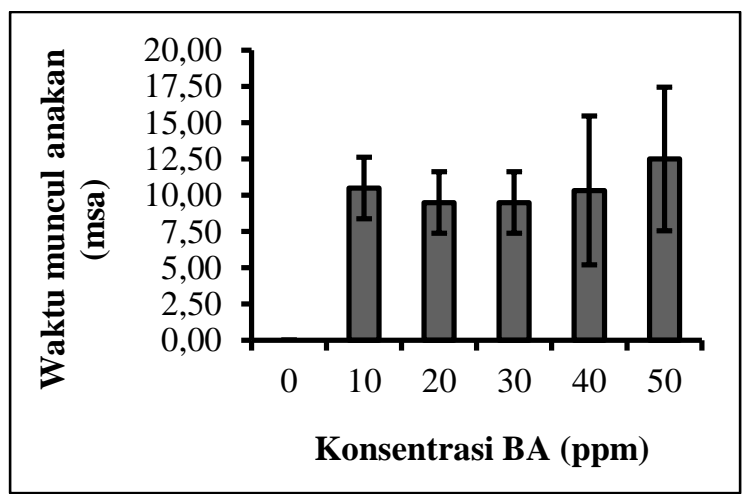

Gambar 5. Pengaruh berbagai konsentrasi benziladenin terhadap waktu muncul anakan spatifilum.

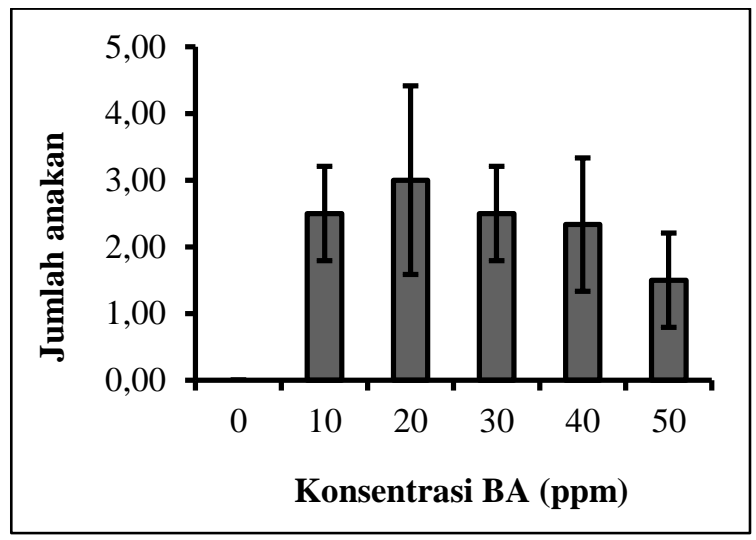

Gambar 6. Pengaruh berbagai konsentrasi benziladenin terhadap jumlah anakan spatifilum.

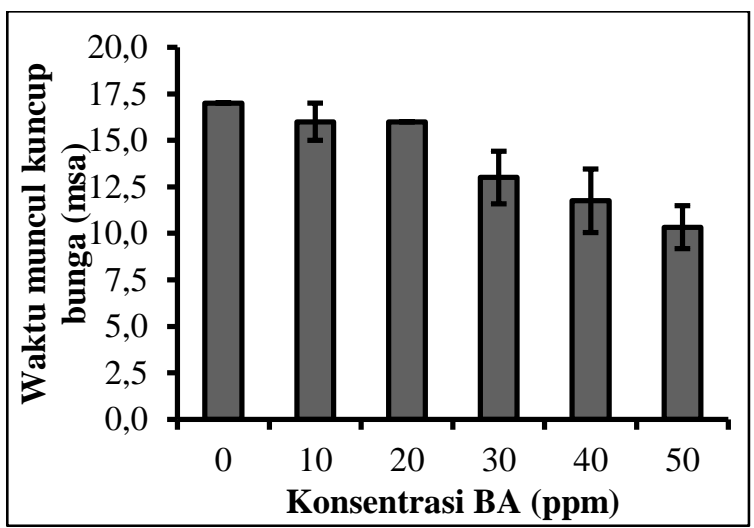

Gambar 7. Pengaruh berbagai konsentrasi benziladenin terhadap waktu muncul kuncup bunga spatifilum.

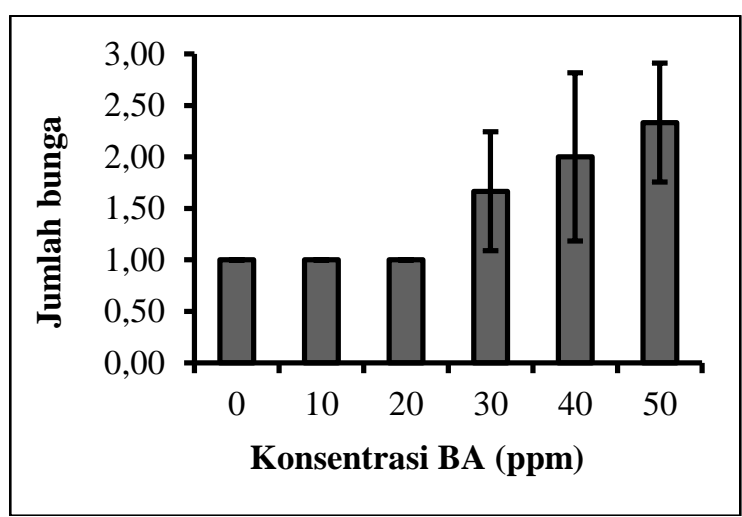

Gambar 8. Pengaruh berbagai konsentrasi benziladenin terhadap jumlah bunga spatifilum.

Hasil penelitian menunjukkan bahwa pemberian benziladenin pada konsentrasi 0 ppm menghasilkan luas daun yang paling sempit dan berbeda dengan konsentrasi 1050 ppm (Gambar 3). Hal ini karena salah satu fungsi benziladenin (golongan 
sitokinin) dapat memacu pembesaran atau ekspansi sel termasuk sel-sel pada daun yang mengakibatkan luas daun tanaman tersebut meningkat (Fuadi dan Hilman, 2008). Hasil penelitian menunjukkan bahwa pemberian benziladenin pada konsentrasi $10-50 \mathrm{ppm}$ cenderung meningkatkan tingkat kehijauan daun pada tanaman spatifilum (Gambar 4). Menurut Fuadi dan Hilman (2008), benziladenin yang memiliki bahan aktif sitokinin sintetik apabila diaplikasikan pada daun dapat merangsang sintesis klorofil yang mampu menghambat penuaan, menghambat kerontokan daun, menghambat degradasi protein, dan meningkatkan diferensiasi vaskular. Hal ini sejalan dengan penelitian yang dilakukan oleh Noventa et al. (2014) bahwa pemberian benziladenin pada bibit anggrek dendrobium dengan konsentrasi $40 \mathrm{mg} / \mathrm{l}$ sudah memberikan pengaruh yang nyata pada variabel pengamatan rata-rata tingkat kehijauan daun dan menghasilkan kandungan klorofil yang tinggi.

Munculnya anakan dan terjadinya pembungaan diperoleh pada tanaman yang sebelumnya sudah pernah berbunga (dewasa) dengan ketinggian $\pm 52 \mathrm{~cm}$ dengan jumlah daun \pm 10 yaitu pada tanaman ulangan 1- 4. Pada tanaman yang ukurannya relatif lebih kecil dengan tinggi tanaman \pm 40 cm dan jumlah daun 8-9 tidak memunculkan bunga, sehingga pada ulangan 5 dan 6 ini sampai akhir penelitian belum berbunga. Tanaman tersebut masih dalam masa juvenile sehingga benziladenin tidak mampu memunculkan anakan dan bunga. Menurut Moningka et al. (2012), tanaman akan berbunga setelah mencapai tingkat kematangan tertentu.

Ukuran bahan tanam dan tingkat kedewasaan tanaman dapat mempengaruhi produktivitas bunga dan anakan spatifilum. Ukuran bahan tanam yang besar dan tanaman sudah dewasa menghasilkan jumlah bunga dan jumlah anakan lebih banyak daripada tanaman yang masih remaja. Umbi yang berukuran besar telah melewati fase pertumbuhan vegetatif dan jaringan sudah dewasa dibandingkan dengan umbi berukuran kecil, yang mengindikasikan bahwa umur bahan tanam tersebut masih muda. Jaringan muda pada umbi yang masih kecil belum memunculkan tunas, karena organ-organ masih aktif membelah belum terdiferensiasi (Moningka et al., 2012). Hal tersebut didukung oleh hasil penelitian El-Shoura dan Arafa (2018) yang menunjukkan bahwa pencelupan umbi sedap malam sebelum tanam pada BA dan GA3 meningkatkan pertumbuhan dan pembungaan tanaman.

Hasil penelitian ini menunjukkan adanya kecenderungan bahwa dengan pemberian benziladenin konsentrasi 20 ppm menghasilkan pertumbuhan fase vegetatif yang paling tinggi, yang ditunjukkan oleh meningkatnya luas daun, tingkat kehijauan daun, jumlah anakan, dan mempercepat waktu muncul anakan. Sebaliknya pada fase generatif dibutuhkan konsentrasi benziladenin yang tinggi, yaitu $50 \mathrm{ppm}$ untuk memacu munculnya kuncup bunga dan jumlah bunga.

\section{KESIMPULAN}

Kesimpulan yang diperoleh dari penelitian ini adalah pemberian benziladenin konsentrasi 10-50 ppm cenderung dapat meningkatkan pertumbuhan spatifilum terutama pada variabel luas daun, tingkat kehijauan daun, waktu muncul anakan, jumlah anakan, waktu muncul kuncup bunga, dan jumlah bunga, tetapi tidak berpengaruh terhadap penambahan tinggi tanaman dan jumlah daun. Konsentrasi benziladenin 20 ppm sudah cukup efisien untuk meningkatkan pertumbuhan spatifilum pada fase vegetatif yang ditunjukkan oleh meningkatnya luas daun, tingkat kehijuan daun, jumlah anakan, dan mempercepat waktu muncul anakan. Pengaruh BA pada fase generatif dibutuhkan konsentrasi yang tinggi, yaitu $50 \mathrm{ppm}$ yang menghasilkan waktu muncul kuncup bunga tercepat dan jumlah bunganya terbanyak. 


\section{DAFTAR PUSTAKA}

Agromedia. 2010. Tips Merawat Tanaman Hias. PT Agromedia Pustaka. Jakarta. 64 hlm.

Andalasari, T.D. 2011. Usaha perbanyakan subang gladiol (Gladiolus hybridus L.).dengan menggunakan benziladenin (BA). Jurnal Penelitian Pertanian Terapan, 11(1): 45-51.

Asra, R., Samarlina, R.A., dan Silalahi, M. 2020. Hormon Tumbuhan. UKI press. Jakarta. $176 \mathrm{hlm}$.

Claudia, L. 2009. Pengaruh Aplikasi Giberelin (GA3) terhadap Pertumbuhan dan Pembungaan Dua Varietas Spatifilum (Spathiphyllum wallisii). (Skripsi). Institut Pertanian Bogor. Bogor. $39 \mathrm{hlm}$.

El-Shoura, H.A.S. and Arafa, F.F 2018. Effect of soaking tuberose bulb (Polianthes tuberosa L.) in growth regulators and thiorea on growth and flowering. Middle East Journal of Applied Sciences, 8(1): 79-82.

Elbohy, N.F.S. 2018. Response of peace lily (Spathiphyllum wallisii Regel) plants to foliar spray with some growth regulator and microelements. Scientific J. Flowers \& Ornamental Plants, 5(4): 275-291.

Fuadi, M. dan Hilman, Y. 2008. Pengaruh konsentrasi Benzil Adenin terhadap kualitas pascapanen Dracaena sanderiana dan Codiaeum variegatum. J. Hort. 18(4): 457-465.
Harjadi, S.S. 2009. Zat Pengatur Tumbuh. Penebar Swadaya. Jakarta. $76 \mathrm{hlm}$.

McConnell, D.B., Chen, J., Henny, R.J. Pennisi, S.V., and Kenne, M.E. 2003. Growth responses of Spathiphyllum cultivars to elevated production temperatures. Acta Hort. 620: 273-279.

Moningka, F.F., Runtunuwu, S.D., dan Paulus, J.M. 2012. Respon pertumbuhan tinggi dan produksi tanaman cengkeh (Syzigium aromaticum L.) terhadap pemberian paklobutrazol. Eugenia, 18(2): 118-127.

Noventa, D.R., Ramadiana, S., Rugayah, dan Yusnita. 2014. Pengaruh Benziladenin dan Vitamin B terhadap pertumbuhan bibit Anggrek Dendrobium. J. Agrotek Tropika, 2(3): 364-368.

Rugayah, Hapsoro, D., Ulumudin, A., dan Motiq, F.W. 2012. Kajian teknik perbanyakan vegetatif pisang Ambon Kuning dengan pembelahan bonggol (corm). Jurnal Agrotropika, 17(2): 58-65.

Salisbury, F.B. dan Ross, C.W. 1995. Fisiologi Tumbuhan: Perkembangan Tumbuhan dan Fisiologi Lingkungan. Jilid tiga. Edisi keempat. Terjemahan Lukman, D.R. dan Sumaryono. ITB. Bandung. $343 \mathrm{hlm}$.

Yusnita. 2003. Kultur jaringan: Cara Memperbanyak Tanaman Secara Efisien. Agro Media Pustaka. Jakarta. 105 hlm. 